Original article

\title{
Cigarette smoke exposure and increased risks of stunting among under-five children
}

\author{
Dyah Dwi Astuti*, Tri Widyastuti Handayani, Duwi Pudji Astuti \\ Poltekkes Kemenkes Surakarta, Letjend Sutoyo, Mojosongo, Surakarta, 57127, Indonesia
}

\section{A R T I C L E I N F O}

\section{Keywords:}

Child malnutrition

Cognitive development

Community

Smoke exposure

Stunting

\begin{abstract}
A B S T R A C T
Background: Stunting describes the condition of chronic malnutrition in children under the age of five, especially in the first 1000 days of life, so that it has an impact on increasing morbidity and mortality. The objective of this study was to analyze the relationship between passive smoking and stunting in children $25-59$ months old. Method: This cross-sectional study used a stratified random sampling technique in 123 children 25-59 months old. Exposure of cigarette smoke is assessed from the length of exposure to cigarette smoke using The Secondhand Smoke Exposure Scale questionnaire.

Results: Bivariate statistical test with Chi-Square and Fisher's Exact Test showed the relationship of stunting to length of cigarette smoke exposure (p-value < 0.000; OR 10.316), water source (p-value 0.040; OR 0.145), hygiene (p-value 0.028; OR 2.742), exclusive breastfeeding (p-value 0.041; OR 0.396), history of pregnancy disorders (p-value 0.035; OR 2.791), and recurrent respiratory infections (p-value < 0.000; OR 21,368). Logistic regression analysis showed that the length of smoking increases the risk of stunting (p-value $<0.000$; OR 13,49), and the most influential variable was recurrent respiratory infections (p-value < 0.000; OR 30.57).

Conclusion: Length of exposure of more than $3 \mathrm{~h}$ a day increases the risk of stunting by 10,316 times. Public policy needs to provide health education in the community and family about the effects of cigarette smoke exposure on the increased risk of stunting in children.
\end{abstract}

\section{Introduction}

Stunting is one of the global health problems to be addressed immediately, illustrates the condition of chronic malnutrition, especially in the first thousand days of life. Hence, it causes the child height growth to be disrupted. ${ }^{1}$ Chronic malnutrition has a long-term impact on cognitive development, as well as on the increase of child morbidity and mortality. ${ }^{2}$ The incidence of stunting in the world is estimated at 156 million, ${ }^{3}$ while in Indonesia, it reaches $30.8 \%$, according to the 2018 Basic Health Research. ${ }^{4}$

The causes of stunting in children are, however, complex, not only solely about malnutrition. ${ }^{5}$ The study stated that knowledge of Indonesian people, especially mothers, about the causes of stunting is still low. ${ }^{6}$ Misinformation about the origins of stunting is related to wrong perceptions and behavior in preventing it. Research on the causes of stunting is usually only associated with nutritional factors; therefore, other factors such as exposure to cigarette smoke are still limited. More comprehensive research on the causes of stunting is needed to provide appropriate information to the public in determining efforts to promote health prevention of stunting. ${ }^{3}$
Smoking is one of the health problems faced in Indonesia. In the Healthy Indonesia Program with the Family Approach, the achievement of the indicator is still low at $44.74 \%$, meaning that only about $44.74 \%$ of family members do not smoke. ${ }^{4}$ This shows that there are still many family members in Indonesia who smoke, which in turn directly increases cigarette smoke exposure to both mother and child. Shah et al. ${ }^{7}$ revealed evidence that $40 \%$ of children under the age of five are exposed to cigarette smoke, and the majority of sources of exposure come from their fathers.

Pregnant women who smoke have a short-term impact on fetal growth $^{8,9}$ and a long-term effect on children's height. ${ }^{10}$ That is due to the nicotine contained in cigarette smoke inhaled by the mother during pregnancy causes impaired embryonic and bone growth, and enters the baby's body during the breastfeeding process. ${ }^{11}$ However, the research has only shown the effect of cigarette smoke exposure on fetal development during pregnancy but has not examined further the relationship of cigarette smoke exposure to the incidence of stunting in under-five children.

The phenomenon explained the importance of research on the causes of stunting for the prevention of stunting in children. This study

\footnotetext{
*Corresponding author. Handphone : + 6281283905102, Tel.: 0271 853869; fax: 0271855388.

E-mail address: astutidyah83@gmail.com (D.D. Astuti).
} 
aimed to analyze the relationship between cigarette smoke exposure and stunting in children 25-59 months. Researchers applied the Health Promotion Model Theory by Nola J. Pender to answer the research question, "Is exposure to cigarette smoke-related to the incidence of stunting in children $25-59$ months?".

\section{Method}

This quantitative study used a cross-sectional approach conducted in a rural village, Surakarta City, Indonesia, in July-August 2019. The sample size was 123 children aged 25-59 months. This research used a stratified random sampling technique. The determination of strata based on the study area was divided administratively by the government into 37 community units (RW). Then each RW was taken 3-4 families randomly.

The number of samples in this study will use the following formula:

$n=\frac{N Z_{1-\alpha / 2}^{2} P(1-P)}{N d^{2}+Z_{1-\alpha / 2}^{2} P(1-P)}$

Based on the method above, the sample with an estimated population of 691 children can be calculated as follows:

$$
\begin{aligned}
& n=\frac{691(1.96)^{2} 0.5(1-0.5)}{691(0.1)^{2}+(1.96)^{2} 0.5(1-0.5)} \\
& =84,32 \text { becomes } 85
\end{aligned}
$$

The researcher anticipates the drop out by adding $10 \%$ of the total sample so that the minimum sample size was 93 children. In this study, 123 children exceeded the minimum sample.

The criteria for inclusion were families with children aged 24-59 months, living in the study area for a minimum of 2 years, having a health record book for mothers and children, willing to become study respondents represented by the parents. Children with a history of chronic cancer and the nephrotic syndrome were excluded from the study. The dependent variable in this study was stunting in children aged $25-59$ months, while the independent variable is exposure to cigarette smoke.

Exposure to cigarette smoke is assessed by the duration of cigarette smoke exposure in children with the questions in the questionnaire. The modified Secondhand Smoke Exposure Scale (SHSES) questionnaire from Shah et al. ${ }^{7}$ was used with validity and reliability to be tested in 30 families with Cronbach's Alpha 0.935. The SHSES questionnaire consisted of a history of child exposure, a history of maternal exposure during pregnancy, and the smoking characteristics of parents. The intended cigarette smoke exposure is a cigarette made from tobacco. Anthropometric data assessment was done by calculating Z-scores and processed by the WHO's World Health Organization Anthro program to assess z-scores. Z-score is assessed with WAZ (weight based on age), WHZ (weight based on height), and HAZ (height based on age).

The questionnaire also consisted of parental identity, history of childbirth, history of exclusive breastfeeding, family income, history of infection, immunization status, family density, and environmental health (Water, Sanitation, and Hygiene/WASH). Water consists of water sources, the distance of water sources with latrines, and drinking water cooking habits. Sanitation consists of ownership of family toilets, requirements for healthy latrines, management of family waste, use of fuel for cooking. Hygiene consists of family hand hygiene habits.

Secondary research data were obtained from maternal and child health books. Data retrieval was done by conducting home visits by following the time contract with the family. The statistical tests used were Chi-Square and Fisher's Exact Test, as well as multivariate logistic regression analysis. The validation of the results was carried out by the expert or the expert in charge of the Nutrition Program at the public health center (PHC) in the study area. The ethical review was conducted by the Ethics Committee of Local Hospital numbered 642/V/ HREC/2019.
Table 1

The relationship of the exposure of cigarette smoke exposure and stunting in

\begin{tabular}{|c|c|c|c|c|c|}
\hline \multirow[t]{2}{*}{ Variable } & \multicolumn{2}{|l|}{ Stunting } & \multirow{2}{*}{$\frac{\text { Total }}{\mathrm{f}(\%)}$} & \multirow[t]{2}{*}{$p$-value } & \multirow[t]{2}{*}{ OR (CI 95\%) } \\
\hline & Yes $(\%)$ & No $(\%)$ & & & \\
\hline \multicolumn{6}{|c|}{$\begin{array}{l}\text { 1. Exposure to Cigarette Smoke in Children } \\
\text { a. Duration }\end{array}$} \\
\hline $\begin{array}{l}\geq 3 \mathrm{~h} \\
\text { per day }\end{array}$ & $14(42.4)$ & $6(6.7)$ & $20(16.3)$ & $<0.000^{\mathrm{a}}$ & $\begin{array}{l}10.316 \\
(3.509-30.323)\end{array}$ \\
\hline $\begin{array}{c}<3 \mathrm{~h} \\
\text { per day }\end{array}$ & $19(57.6)$ & $84(93.3)$ & $103(83.7)$ & & \\
\hline $\begin{array}{l}\text { Total } \\
\text { b. Source }\end{array}$ & $33(100)$ & $90(100)$ & $123(100)$ & & \\
\hline Home & $21(63.7)$ & $56(62.2)$ & $77(62.6)$ & $1.000^{\mathrm{a}}$ & $\begin{array}{l}1.063 \\
(0.464-2.430)\end{array}$ \\
\hline $\begin{array}{l}\text { Public } \\
\text { places }\end{array}$ & $12(36.3)$ & $34(37.8)$ & $46(37.4)$ & & \\
\hline Total & $33(100)$ & $90(100)$ & $123(100)$ & & \\
\hline \multicolumn{6}{|c|}{$\begin{array}{l}\text { 2. Exposure to Cigarette Smoke in Pregnant Women } \\
\text { a. History }\end{array}$} \\
\hline Yes & $22(66.7)$ & $70(77.8)$ & $92(74.8)$ & $0.306^{\mathrm{a}}$ & $\begin{array}{l}0.571 \\
(0.238-1.375)\end{array}$ \\
\hline No & 11 (33.3) & $20(22.2)$ & $31(25.2)$ & & \\
\hline $\begin{array}{l}\text { Total } \\
\text { b. Source }\end{array}$ & $33(100)$ & $90(100)$ & $123(100)$ & & \\
\hline Home & 15 (45.5) & $49(54.4)$ & $64(52)$ & $0.496^{\mathrm{a}}$ & $\begin{array}{l}0.697 \\
(0.313-1.553)\end{array}$ \\
\hline $\begin{array}{l}\text { Public } \\
\text { places }\end{array}$ & $18(54.5)$ & $41(45.5)$ & $59(48)$ & & \\
\hline Total & $33(100)$ & $90(100)$ & $123(100)$ & & \\
\hline \multicolumn{6}{|c|}{$\begin{array}{l}\text { 3. Description of The Smoking Father } \\
\text { a. Smoker father }\end{array}$} \\
\hline Yes & $21(63.6)$ & $58(64.4)$ & $79(64.2)$ & $1.00^{\mathrm{a}}$ & $\begin{array}{l}0.966 \\
(0.421-2.215)\end{array}$ \\
\hline No & $12(36.4)$ & $32(35.6)$ & $44(35.8)$ & & \\
\hline \multicolumn{6}{|c|}{ b. Duration } \\
\hline$<3$ yr & $2(9.5)$ & $0(0)$ & $2(2.5)$ & $0.068^{\mathrm{b}}$ & $\begin{array}{l}0.247 \\
(0.167-0.365)\end{array}$ \\
\hline$\geq 3 \mathrm{yr}$ & 19 (90.5) & $58(100)$ & 77 (97.5) & & \\
\hline Total & $21(100)$ & $58(100)$ & $79(100)$ & & \\
\hline \multicolumn{6}{|c|}{ c. Frequency } \\
\hline $\begin{array}{c}<3 x \\
\text { per day }\end{array}$ & $0(0)$ & $3(5.2)$ & $3(3.8)$ & $0.561^{\mathrm{b}}$ & $\begin{array}{l}0.724 \\
(0.630-0.832)\end{array}$ \\
\hline $\begin{array}{l}\geq 3 x \\
\text { per day }\end{array}$ & $21(100)$ & $55(94.8)$ & $76(96.2)$ & & \\
\hline Total & $21(100)$ & $58(100)$ & $79(100)$ & & \\
\hline
\end{tabular}
children 25-59 Months ( $\mathrm{n}=123)$.

Note:

a Bivariate Test Results with Chi-Square.

b Bivariate Test Results with Fisher's Exact Test.

\section{Result}

The prevalence of stunting in children aged 25-59 months was estimated at $33(26.83 \%)$ children. Exposure to cigarette smoke in this study is assessed from the length of exposure to cigarette smoke for a day. The duration of cigarette smoke exposure had a significant relationship with stunting in children $25-59$ months (p-value $=0.000$; OR $=10.316$; 95\% CI 3.509-30.323) (Table 1). Long exposure to cigarette smoke more than $3 \mathrm{~h}$ per day could increase the risk of stunting by 10.316 times. The majority of cigarette smoke exposure originated from paternal (father) as many as $21(63.6 \%)$, and the majority of father's smoking for more than three years was 77 (97.5\%).

This study did not analyze the relationship between nutrition and stunting. The variables that had a significant relationship with stunting in 25-59 months (Table 2) in this study were exclusive breastfeeding (p-value $=0.041 ;$ OR $=0.396 ; 95 \%$ CI $0.175-0.895$ ), a history of pregnancy disorders ( $\mathrm{p}$-value $=0.035 ; \mathrm{OR}=2.791 ; 95 \% \mathrm{CI}$ 1.163-6.698), recurrent respiratory infections (p-value $=0.000$; $\mathrm{OR}=21,368 ; 95 \%$ CI 5584-81,778), water source ( $\mathrm{p}$-value $=0.040$; $\mathrm{OR}=0.145 ; 95 \% \mathrm{CI} 0.018-1.137$ ) and hygiene or hand washing habits 
Table 2

Factors related to stunting in children 25-59 Months ( $\mathrm{n}=123$ ).

\begin{tabular}{|c|c|c|c|c|c|}
\hline \multirow[t]{2}{*}{ Variable } & \multicolumn{2}{|l|}{ Stunting } & \multirow{2}{*}{$\begin{array}{l}\text { Total } \\
\text { f (\%) }\end{array}$} & \multirow[t]{2}{*}{$p$-value } & \multirow[t]{2}{*}{ OR (CI 95\%) } \\
\hline & Yes $(\%)$ & No $(\%)$ & & & \\
\hline \multicolumn{6}{|l|}{ Individual Factor } \\
\hline \multicolumn{6}{|l|}{ 1. Sex } \\
\hline a. Male & $18(54.5)$ & $45(50)$ & $63(51.2)$ & $0.808^{\mathrm{a}}$ & $1.200(0.539-2.6710$ \\
\hline b. Female & $15(45.5)$ & $45(50)$ & $60(48.8)$ & & \\
\hline Total & $33(100)$ & $90(100)$ & $123(100)$ & & \\
\hline \multicolumn{6}{|l|}{ 2. Age } \\
\hline a. $25-36$ months & $12(36.4)$ & $31(34.4)$ & $43(35)$ & $1.000^{\mathrm{a}}$ & $1.088(0.473-2.499)$ \\
\hline b. $37-60$ months & $21(63.6)$ & $59(65.6)$ & $80(65)$ & & \\
\hline Total & $33(100)$ & $90(100)$ & $123(100)$ & & \\
\hline \multicolumn{6}{|l|}{ 3. History of preterm birth } \\
\hline a. Gestational age $<37$ weeks & $3(9.09)$ & $3(3.33)$ & $6(4.9)$ & $0.341^{\mathrm{b}}$ & $2.900(0.555-15.149)$ \\
\hline b. Gestational age $\geq 37$ weeks & $30(90.91)$ & $87(96.67)$ & $117(95.1)$ & & \\
\hline Total & $33(100)$ & $90(100)$ & $123(100)$ & & \\
\hline 4. History of Low Birth Weight & & & & & \\
\hline a. Yes & $3(9.09)$ & $9(10)$ & $12(9.8)$ & $1.000^{\mathrm{a}}$ & $0.900(0.228-3.549)$ \\
\hline b. No & $30(90.91)$ & $81(90)$ & $111(90.2)$ & & \\
\hline Total & $33(100)$ & $90(100)$ & $123(100)$ & & \\
\hline 5. Body length & & & & & \\
\hline a. Birth length $<48 \mathrm{~cm}$ & $11(33.33)$ & $25(27.8)$ & $36(29.3)$ & $0.707^{\mathrm{a}}$ & $1.300(0.551-3.067)$ \\
\hline b. Birth length $\geq 48 \mathrm{~cm}$ & $22(66.67)$ & $65(72.22)$ & $87(70.7)$ & & \\
\hline Total & $33(100)$ & $90(100)$ & $123(100)$ & & \\
\hline 6. Exclusive breastfeeding & & & & & \\
\hline a. No & $18(54.55)$ & $29(32.22)$ & $47(38.2)$ & $0.041^{\mathrm{a}}$ & $0.396(0.175-0.895)$ \\
\hline b. Yes & $15(45.45)$ & $61(67.78)$ & $76(61.8)$ & & \\
\hline Total & $33(100)$ & $90(100)$ & $123(100)$ & & \\
\hline 7. Duration of breastfeeding & & & & & \\
\hline a. $<2 \mathrm{yr}$ & $17(51.51)$ & $48(53.33)$ & $65(52.8)$ & $1.000^{\mathrm{a}}$ & $0.930(0.418-2.066)$ \\
\hline b. $\geq 2 \mathrm{yr}$ & $16(48.89)$ & $42(46.67)$ & $58(47.2)$ & & \\
\hline Total & $33(100)$ & $90(100)$ & $123(100)$ & & \\
\hline Maternal and Paternal Factor & & & & & \\
\hline 8. Gestational age & & & & & \\
\hline a. At risk $(<20 \mathrm{yr}$ or $>35 \mathrm{yr})$ & $6(18.18)$ & $12(13.33)$ & $18(14.6)$ & $0.699^{\mathrm{a}}$ & $1.444(0.494-4.225)$ \\
\hline b. Not at risk $(20-35 \mathrm{yr})$ & $27(81.82)$ & $78(86.67)$ & $105(85.4)$ & & \\
\hline Total & $33(100)$ & $90(100)$ & $123(100)$ & & \\
\hline 9. History of chronic energy deficiency & & & & & \\
\hline a. Yes (Mid Upper Arm Circumference/MUAC $<23,5 \mathrm{~cm}$ ) & $5(15.15)$ & $6(6.67)$ & $11(8.9)$ & $0.269^{\mathrm{a}}$ & $2.500(0.708-8.827)$ \\
\hline b. No $(\mathrm{MUAC} \geq 23,5 \mathrm{~cm}$ & $28(84.85)$ & $84(93.33)$ & $112(91.1)$ & & \\
\hline Total & $33(100)$ & $90(100)$ & $123(100)$ & & \\
\hline 10. History of pregnancy disorder & & & & & \\
\hline a. Yes & $13(39.39)$ & $17(18.89)$ & $30(24.4)$ & $0.035^{\mathrm{a}}$ & $2.791(1.163-6.698)$ \\
\hline b. No & $20(60.61)$ & $73(81.11)$ & $93(75.6)$ & & \\
\hline Total & $33(100)$ & $90(100)$ & $123(100)$ & & \\
\hline 11. Parents' body height & & & & & \\
\hline a. Father & & & & & \\
\hline$<155 \mathrm{~cm}$ & $0(0)$ & $0(0)$ & $0(0)$ & - & - \\
\hline$\geq 155 \mathrm{~cm}$ & $33(100)$ & $90(100)$ & $123(100)$ & & \\
\hline Total & $33(100)$ & $90(100)$ & $123(100)$ & & \\
\hline b. Mother & & & & & \\
\hline$<150 \mathrm{~cm}$ & $5(15.15)$ & $5(5.56)$ & $10(8.1)$ & $0.176^{\mathrm{a}}$ & $3.036(0.818-11.263)$ \\
\hline$\geq 150 \mathrm{~cm}$ & $28(84.85)$ & $85(94.44)$ & $113(91.9)$ & & \\
\hline Total & $33(100)$ & $90(100)$ & $123(100)$ & & \\
\hline Infection Factor & & & & & \\
\hline 12. Recurrent respiratory tract infections & & & & & \\
\hline a. $\geq 3 x$ in a year & $14(42.42)$ & $3(3.33)$ & $17(13.8)$ & $<0.000^{\mathrm{a}}$ & $21.368(5.584-81.778)$ \\
\hline b. $<3 x$ in a year & $19(57.58)$ & $87(96.67)$ & $106(86.2)$ & & \\
\hline Total & $33(100)$ & $90(100)$ & $123(100)$ & & \\
\hline 13. Recurrent digestive tract infections & & & & & \\
\hline a. $\geq 3 x$ in a year & $0(0)$ & $8(88.89)$ & $10(8.1)$ & $0.174^{\mathrm{b}}$ & $1.402(1.249-1.575)$ \\
\hline b. $<3 x$ in a year & $33(100)$ & $82(91.11)$ & $113(91.9)$ & & \\
\hline Total & $33(100)$ & $90(100)$ & $123(100)$ & & \\
\hline 14. History of basic immunization & & & & & \\
\hline a. Not complete & $4(12.12)$ & $5(5.56)$ & $9(7.3)$ & $0.396^{\mathrm{a}}$ & $0.426(0.107-1.696)$ \\
\hline b. Complete & $29(87.88)$ & $85(94.44)$ & $114(92.7)$ & & \\
\hline Total & $33(100)$ & $90(100)$ & $123(100)$ & & \\
\hline Home Environment Factor & & & & & \\
\hline 15. Level of family income & & & & & \\
\hline a. $<\operatorname{Rp~1.802.700,00~(Low~Income)~}$ & $4(12.12)$ & $8(8.89)$ & $12(9.8)$ & $0.847^{\mathrm{a}}$ & $1.414(0.396-5.048)$ \\
\hline b. $\geq \operatorname{Rp~1.802.700,00~(Above~Standards~Income)~}$ & $29(87.88)$ & $82(91.11)$ & $111(90.2)$ & & \\
\hline Total & $33(100)$ & $90(100)$ & $123(100)$ & & \\
\hline 16. Family member & & & & & \\
\hline a. $>5$ persons & $24(72.73)$ & 69 (76.67) & $93(75.6)$ & $0.831^{\mathrm{a}}$ & $1.232(0.497-3.057)$ \\
\hline b. $\leq 5$ persons & $9(27.27)$ & $21(23.33)$ & $30(24.4)$ & & \\
\hline
\end{tabular}


Table 2 (continued)

\begin{tabular}{|c|c|c|c|c|c|}
\hline \multirow[t]{2}{*}{ Variable } & \multicolumn{2}{|l|}{ Stunting } & \multirow{2}{*}{$\begin{array}{c}\text { Total } \\
\mathrm{f}(\%)\end{array}$} & \multirow[t]{2}{*}{$p$-value } & \multirow[t]{2}{*}{ OR (CI 95\%) } \\
\hline & Yes $(\%)$ & No (\%) & & & \\
\hline Total & $33(100)$ & $90(100)$ & $123(100)$ & & \\
\hline \multicolumn{6}{|c|}{ 17. Stimulation of growth and development } \\
\hline a. Less & $13(39.39)$ & $20(22.22)$ & $33(26.8)$ & $0.940^{\mathrm{a}}$ & $2.275(0.966-5.360)$ \\
\hline b. Appropriate & $20(60.61)$ & $70(77.78)$ & $90(73.2)$ & & \\
\hline Total & $33(100)$ & $90(100)$ & $123(100)$ & & \\
\hline \multicolumn{6}{|l|}{ 18. Mother's education } \\
\hline a. Elementary & $3(9.09)$ & $13(14.44)$ & $16(13)$ & $0.632^{\mathrm{a}}$ & $0.592(0.158-2.227)$ \\
\hline b. Middle-senior high & $30(90.91)$ & $77(85.56)$ & 107(87) & & \\
\hline Total & $33(100)$ & $90(100)$ & $123(100)$ & & \\
\hline \multicolumn{6}{|l|}{ 19. Father's education } \\
\hline a. Elementary & $3(9.09)$ & $15(16.67)$ & 18 (14.6) & $0.444^{\mathrm{a}}$ & $0.500(0.135-1.853)$ \\
\hline b. Middle-senior high & $30(90.91)$ & $75(83.33)$ & $105(85.4)$ & & \\
\hline Total & $33(100)$ & $90(100)$ & $123(100)$ & & \\
\hline \multicolumn{6}{|l|}{ 20. Water (clean water source) } \\
\hline a. Not good & $1(3)$ & $16(17.77)$ & $17(13.8)$ & $0.040^{\mathrm{b}}$ & $0.145(0.018-1.137)$ \\
\hline b. Good & $32(97)$ & $74(82.23)$ & $106(86.2)$ & & \\
\hline Total & $33(100)$ & $90(100)$ & $123(100)$ & & \\
\hline \multicolumn{6}{|c|}{ 21. Sanitation (facility of environmental health) } \\
\hline a. Not good & $9(27.27)$ & $17(18.89)$ & $26(21.1)$ & $0.447^{\mathrm{a}}$ & $1.610(0.635-4.083)$ \\
\hline b. Good & $24(72.73)$ & $73(81.11)$ & $97(78.9)$ & & \\
\hline Total & $33(100)$ & $90(100)$ & $123(100)$ & & \\
\hline \multicolumn{6}{|l|}{ 22. Hygiene (handwashing) } \\
\hline a. Not good & $16(48.48)$ & $23(25.56)$ & $39(31.7)$ & $0.028^{\mathrm{a}}$ & $2.742(1.194-6.293)$ \\
\hline b. Good & $17(51.52)$ & $67(74.44)$ & $84(68.3)$ & & \\
\hline Total & $33(100)$ & $90(100)$ & $123(100)$ & & \\
\hline \multicolumn{6}{|l|}{ 23. Anthropometric Value } \\
\hline \multicolumn{6}{|l|}{ a. WAZ-score } \\
\hline$<-2 \mathrm{SD}$ and $>+2 \mathrm{SD}$ & $7(21.21)$ & $11(12.22)$ & $18(14.63)$ & 0.336 & $0.517(0.182-1.472)$ \\
\hline-2 SD until +2 SD & $26(78.79)$ & $79(87.78)$ & $105(85.37)$ & & \\
\hline Total & $33(100)$ & $90(100)$ & $123(100)$ & & \\
\hline \multicolumn{6}{|l|}{ b. WHZ-score } \\
\hline$<-2 \mathrm{SD}$ and $>+2 \mathrm{SD}$ & $2(06.06)$ & $11(12.22)$ & $13(10.57)$ & 0.513 & $2.158(0.452-10.300)$ \\
\hline-2 SD until +2 SD & $31(93.94)$ & $79(87.78)$ & $110(89.43)$ & & \\
\hline Total & $33(100)$ & $90(100)$ & $123(100)$ & & \\
\hline
\end{tabular}

Note:

${ }^{\text {a }}$ Bivariate Test Results with Chi-Square.

b Bivariate Test Results with Fisher's Exact Test.

(p-value $=0.028 ;$ OR $=2.742 ; 95 \%$ CI 1.194-6.293).

Exposure to cigarette smoke is a long exposure to cigarette smoke more than $3 \mathrm{~h}$ a day, which continually occurs, especially in the first 1000 days of life. Recurrent respiratory infections are respiratory infections more than three times a month caused by the risk of exposure to cigarette smoke, such as acute respiratory infection (ARI) and pneumonia. A history of pregnancy disorders is a pregnancy disorder that may be caused by exposure to cigarette smoke, such as intrauterine growth restriction (IUGR). Exclusive breastfeeding is defined as breastfeeding for infants from birth to 6 months of age without providing additional food. Water sources are assessed from the distance of drinking water sources with family toilets and protection from chemical and fecal contamination. Hygiene is evaluated from families having handwashing facilities, the habit of handwashing with running water and soap after defecation, before eating, and preparing food.
Table 3 Describes the results of the logistic regression test to find out the factors most related with stunting in under-five children. The variables that influenced the incidence of stunting were recurrent respiratory infections (p-value $=0.000$; OR 30.57; 95\% CI 5.40-172.93), duration of exposure to cigarette smoke ( $\mathrm{p}$-value $=0.000$; $\mathrm{OR}=13.49$; CI 95\% 3.55-51.33), and water sources ( $\mathrm{p}$-value $=0.041$; OR $=0.024$; CI 95\% 0.01-0.85). However, the most related to the incidence of stunting was recurrent respiratory infections.

\section{Discussion}

\subsection{Characteristics of children and families related to stunting}

The results of this study showed that the sex of the child was not associated with stunting in children. The results of other studies showed

Table 3

Factors that are Most Associated with Stunting in Children 25-59 Months $(\mathrm{n}=123)$.

\begin{tabular}{|c|c|c|c|c|c|c|c|}
\hline Variable & Coefficient & S.E & Wald & df & $p$ value & OR & CI 95\% (min-max) \\
\hline Recurrent diarrhea & -0.390 & 1.179 & 0.110 & 1 & 0.741 & 0.68 & $0.067-6.82$ \\
\hline Recurrent respiratory infections & 3.420 & 0.884 & 14.966 & 1 & $<0.000$ & 30.57 & $5.40-172.93$ \\
\hline History of Pregnancy Disorders & 1.039 & 0.720 & 2.082 & 1 & 0.149 & 2.82 & $0.69-11.58$ \\
\hline Exclusive breastfeeding & 0.725 & 0.614 & 1.395 & 1 & 0.238 & 2.06 & $0.62-6.87$ \\
\hline Mother's Height & -0.907 & 0.991 & 0.837 & 1 & 0.360 & 0.404 & $0.06-2.82$ \\
\hline Water (clean water source) & -3.738 & 1.827 & 4.184 & 1 & 0.041 & 0.024 & $0.01-0.85$ \\
\hline Hygiene & 1.224 & 0.656 & 3.483 & 1 & 0.062 & 3.40 & $0.94-12.30$ \\
\hline Exposure length to cigarette smoke in children & 2.602 & 0.682 & 14.566 & 1 & $<0.000$ & 13.49 & $3.55-51.33$ \\
\hline Constant & -2.807 & 0.517 & 29.456 & 1 & 0.000 & 0.060 & \\
\hline
\end{tabular}


that boys had a strong relationship with the incidence of stunting. ${ }^{12}$ This may be related to cultural issues, gender preferences, and differences in eating practices between boys and girls. Boys are biologically more vulnerable to morbidity and mortality. ${ }^{13}$

In this study, the majority of families had an income above the standards set by the government. Children who had non-smoking fathers had less growth disturbance compared to children with smoking fathers. In families with non-smoking fathers, the possibility to consume foods with various nutrients needed by children is higher such as animal protein, which is considered expensive. The results also showed that fathers who smoke spend money to smoke the same value as to buy food such as eggs, meat, milk, oil, and vegetables. ${ }^{14}$

The results of the study showed that the majority of parents had high middle-senior level education. Parental education may be related to knowledge about stunting. Research results in Indonesia state that only $66(2.1 \%)$ hear, read, and know about stunting. ${ }^{3}$ Lack of knowledge will lead to low access to health facilities. ${ }^{15}$ This showed that public knowledge about stunting still needs to be improved to form behaviors that support stunting prevention. ${ }^{6}$

\subsection{Cigarette smoke exposure and increased risks of stunting}

In this current study, the duration of cigarette smoke exposure had a significant relationship with stunting in children 25-59 months. Exposure to cigarette smoke more than $3 \mathrm{~h}$ per day increased the incidence of stunting by 10.316 times. However, a study result stated that exposure to cigarette smoke from the environment does not have a significant relationship with the prevalence of stunting. ${ }^{16}$ The difference in the results may be due to the length of exposure to cigarette smoke. Prolonged exposure to cigarette smoke causes increased levels of nicotine in the body. Nicotine can reduce the $30-40 \%$ oxygen supply and disturb the absorption of nutrients such as calcium, minerals, and vitamin $\mathrm{C}$ that are important for the height growth of children. ${ }^{8}$

The majority of children with stunting in this study had a smoker father with more than three years of smoking and a frequency of smoking more than three times a day. This showed that the exposure to cigarette smoke was constant and a long period of time, especially in the early 1000 days of a child's life (golden period of growth). Exposure to cigarette smoke in the first 1000 days of life increases the risk of stunting by 2.04 times. ${ }^{17}$ The majority of families did not have a smoking ban at home. A study by Shah et al. ${ }^{7}$ showed that children who lived with smokers had higher nicotine levels of $0.36 \mathrm{ng} / \mathrm{mL}$ compared to those who did not live with smokers.

A history of pregnancy disorders in mothers had a significant relationship with stunting in children in this current study. ${ }^{18}$ stated that the disturbance in the preconception period and maternal pregnancy is related to the incidence of stunting in children. Exposure to cigarette smoke during pregnancy can increase IUGR, premature birth, and low birth weight. Exposure to cigarette smoke causes the mediator of insulin-like growth factor (IGF), insulin-like growth factor binding protein 2 (IGFBP-3) to be disrupted. This harms children's growth. ${ }^{19}$

There was a relationship between recurrent respiratory infections and stunting in children. One of the effects of exposure to cigarette smoke in children is to reduce the function of cilia and changes in the colonization of normal flora bacteria that function as the body's defenses. ${ }^{20}$ The impaired function causes the child to be vulnerable to respiratory infections such as ARI and pneumonia. ${ }^{21}$ Recurrent respiratory infections cause inflammatory processes and fever, which increase nutritional requirements for metabolism, and the child experiences a decrease in appetite. ${ }^{22}$

The bivariate test result shows that exclusive breastfeeding was a protective factor for stunting in children. It was supported by a study by $^{23}$ that breast milk prevented stunting by 1.3 times. Early breastfeeding will make children get colostrums, which is rich in nutrients for long-term child development. The provision of maternal colostrum in the first week of life affects the maturation of the gastrointestinal tract and increases the body's immunity. ${ }^{10}$ stated that nicotine could enter a baby's body during the breastfeeding process, thus interfering with the absorption of nutrients in breast milk, especially zinc, thereby increasing the risk of growth disorders.

In this study, another variable related to stunting in children was environmental health. The source of clean water and handwashing had a relationship with the incidence of stunting in children. ${ }^{24}$ stated that water, sanitation, and hygiene had a strong relationship with the incidence of stunting in children. Unclean water sources cause the gastrointestinal tract to be exposed to bacteria and produce enterotoxins that interfere with the barrier layer of the digestive tract (environmental enteric dysfunction/EED). Washing hands prevents oral-fecal transmission in the first 1000 days of life in both pregnant women and children. ${ }^{25}$

The variables associated with the incidence of stunting from the multivariate analysis were exposed to cigarette smoke, clean water sources, and respiratory tract infections. These three variables might be interconnected. Inadequate environmental health causes children to be vulnerable to diarrhea and diarrhea might cause inadequate nutritional intake in children, so that they experience decreased endurance and are susceptible to respiratory infections. ${ }^{26}$ This might give an idea for a further study on a relationship between environmental health and respiratory infections to the incidence of stunting.

This study provides fundamental knowledge that the incidence of stunting in children is not only caused by factors directly related to nutrition such as exclusive breastfeeding and nutritional status but also due to other factors such as exposure to cigarette smoke. Health Promotion Model Theory by Nola J. Pender stated that people's perceptions influence public health behavior in looking at health problems, especially the occurrence of stunting in children. Increased knowledge about the occurrence of stunting can improve people's perception, which subsequently forms positive behavior towards efforts to prevent stunting in children.

The research method used in this study was still weak, so the results of the study may not be generalizable. The limitation of this study is the observation of the relationship between risk factors and effects may not be done at the same time. Exposure to cigarette smoke may have occurred in the past, but the assessment is carried out at this time. Therefore, further research on the occurrence of stunting can be done with a case-control or prospective approach. This study also provides recommendations for experimental research on methods of providing health promotion for the prevention of stunting.

\section{Conclusion}

In addition to nutrition, it turns out there are several other factors that can cause stunting in children 25-59 months old such as exclusive breastfeeding, water source, hygiene, prolonged exposure to cigarette smoke, and recurrent respiratory infections. This study concludes that the duration of cigarette smoke exposure has a significant relationship with stunting in children 25-59 months old. The study recommends that health policies in Indonesia for handling stunting pay attention to not only issues of nutrition, sanitation, education, health services, and social protection, but also the handling of family members who smoke. Providing education to the community and family about the impact of cigarette smoke exposure on the increased risk of stunting in children.

\section{Financial Support}

We express our gratitude to the Directure of Health Polytechnic of Health Ministry Surakarta for permitting and supporting this study.

\section{Authorship}

Dyah Dwi Astuti as a research leader (pediatric nursing spesialist). Tri Widyastuti Handayani as co leader (community nursing 
spesialist).

Duwi Pudji Astuti as co leader (contribution about statistic method).

\section{Ethical standards disclosure}

Manuscripts describing research involving human participants must include the following statement: "This study was conducted according to the guidelines laid down in the Declaration of Helsinki and all procedures involving research study participants were approved by the Ethics Committee of Dr. Moewardi Local Hospital numbered 642/V/ HREC/2019. Written informed consent was obtained from all subjects/ patients." Where verbal consent was obtained, this must be followed by a statement such as: "Verbal consent was witnessed and formally recorded."

\section{Declaration of competing interest}

There are no conflict interest on this study.

\section{Acknowledgements}

Thank you to the Directure of Health Polytechnic of Health Ministry Surakarta for funding this research (financial support).

\section{Appendix A. Supplementary data}

Supplementary data to this article can be found online at https:// doi.org/10.1016/j.cegh.2020.02.029.

\section{References}

1. Dorsey JL, Manohar S, Neupane S, Shrestha B, Klemm RDW, West KP. Individual, household, and community level risk factors of stunting in children younger than 5 years: findings from a national surveillance system in Nepal. Matern Child Nutr. 2018;14(1):1-16. https://doi.org/10.1111/mcn.12434.

2. Vilcins D, Sly PD, Jagals P. Environmental risk factors associated with child stunting: a systematic review of the literature. Annals of Global Health. 2018;84(4):551-562. https://doi.org/10.29024/aogh.2361.

3. Hall C, Bennett C, Crookston B, et al. Maternal knowledge of stunting in rural Indonesia. Int $J$ Child Health Nutr. 2018;7(4):139-145. https://doi.org/10.6000/ 1929-4247.2018.07.04.2.

4. Ministry of Health of the Republic of Indonesia. Perkembangan PISPK (Program Indonesia Sehat Dengan Pendekatan Keluarga). 2018; 2018.

5. Cumming O, Cairncross S. Can water, sanitation and hygiene help eliminate stunting? Current evidence and policy implications. Matern Child Nutr. 2016;12:91-105. https://doi.org/10.1111/mcn.12258.

6. Haines AC, Jones AC, Kriser H, et al. Analysis of rural Indonesian mothers knowledge, attitudes, and beliefs regarding stunting. Arch Med Res. 2018;6(11):1-13 Retrieved from https://journals.ke-i.org/index.php/mra/article/view/1872.

7. Shah S, Kanaan M, Huque R, et al. Secondhand smoke exposure in primary school children: a survey in Dhaka, Bangladesh. Nicotine Tob Res. 2019;21(4):416-423. https://doi.org/10.1093/ntr/ntx248.

8. Ramadani M, Utomo B, Achadi EL, Gunardi H. Prenatal secondhand smoke exposure: correlation between. Osong Public Health and Research Perspectives. 2019;10(4):234-239.

9. Quelhas D, Kompala C, Wittenbrink B, et al. The association between active tobacco use during pregnancy and growth outcomes of children under five years of age: a systematic review and meta-analysis. BMC Publ Health. 2018;18(1):1-17. https://doi. org/10.1186/s12889-018-6137-7.

10. Muraro AP, Gonçalves-Silva RMV, Moreira NF, et al. Effect of tobacco smoke exposure during pregnancy and preschool age on growth from birth to adolescence: a cohort study. BMC Pediatr. 2014;14(1):1-9. https://doi.org/10.1186/1471-243114-99.

11. Goyal N, Canning D. Exposure to ambient fine particulate air pollution in utero as a risk factor for child stunting in Bangladesh. Int J Environ Res Publ Health. 2018;15(1) https://doi.org/10.3390/ijerph15010022.

12. Cruz LMG, Azpeitia GG, Súarez DR, Rodríguez AS, Ferrer JFL. Factors associated with Stunting among children aged 0 to 59 months from the central region of Mozambique. 9. Nutrients; 2017:491. https://doi.org/10.3390/nu9050491.

13. Dake SK, Solomon FB, Bobe TM, Tekle HA. Predictors of stunting among children 6-59 months of age in Sodo Zuria District,South Ethiopia: a community based crosssectional study. BMC Nutrition. 2019;5:23. https://doi.org/10.1186/s40795019-0287-6.

14. Wijaya-Erhardt M. Nutritional status of Indonesian children in low-income households with fathers that smoke. Osong Public Health and Research Perspectives. 2019;10(2):64-71. https://doi.org/10.24171/j.phrp.2019.10.2.04.

15. Thakur B, Kar S, Pathak M, Thakur N. Public-private share in maternal health care services utilization in India: a multinomial logistic regression analysis from three consecutive survey data. Clinical Epidemiology and Global Health. 2019;7(1):22-28. https://doi.org/10.1016/j.cegh.2017.12.003.

16. Dadras O, Chapman RS. Biomass fuel smoke and stunting in early childhood : finding from a national survey in Nepal. $J$ Health Res. 2017;31(August):1-9. https://doi.org/ 10.14456/jhr.2017.62.

17. Pem D. Factors affecting early childhood growth and development: golden 1000 days. Advanced Practices in Nursing. 2016:1-4. https://doi.org/10.4172/2573-0347. 1000101 01(01).

18. Young MF, Nguyen PH, Casanova IG, et al. Role of maternal preconception nutrition on offspring growth and risk of stunting across the first 1000 days in Vietnam: a prospective cohort study. PloS One. 2018;13(8):1-13. https://doi.org/10.1371/ journal.pone.0203201.

19. de Brito ML, Nunes M, Bernardi JR, Bosa VL, Goldani MZ, da Silva CH. Somatic growth in the first six months of life of infants exposed to maternal smoking in pregnancy. BMC Pediatr. 2017;17(1):1-9. https://doi.org/10.1186/s12887-0170819-7.

20. Bugova G, Janickova M, Uhliarova B, Babela R, Jesenak M. The effect of passive smoking on bacterial colonisation of the upper airways and selected laboratory parameters in children. Acta Otorhinolaryngol Ital: Organo Ufficiale Della Societa Italiana Di Otorinolaringologia e Chirurgia Cervico-Facciale. 2018;38(5):431-438. https://doi.org/10.14639/0392-100X-1573.

21. Verhagen LM, Hermsen M, Rivera-Olivero IA, et al. Nasopharyngeal carriage of respiratory pathogens in Warao Amerindians: significant relationship with stunting. Trop Med Int Health. 2017;22(4):407-414. https://doi.org/10.1111/tmi.12835.

22. Tazinya AA, Halle-Ekane GE, Mbuagbaw LT, Abanda M, Atashili J, Obama MT. Risk factors for acute respiratory infections in children under five years attending the Bamenda regional hospital in Cameroon. BMC Pulm Med. 2018;18(1):1-8. https:// doi.org/10.1186/s12890-018-0579-7.

23. Muldiasman M, Kusharisupeni K, Laksminingsih E, Besral B. Can early initiation to breastfeeding prevent stunting in 6-59 months old children? Journal of Health Research. 2018;32(5):334-341. https://doi.org/10.1108/JHR-08-2018-038.

24. Saxton J, Rath S, Nair N, et al. Handwashing, sanitation and family planning practices are the strongest underlying determinants of child stunting in rural indigenous communities of Jharkhand and Odisha, Eastern India: a cross-sectional study. Matern Child Nutr. 2016;12(4):869-884. https://doi.org/10.1111/mcn.12323.

25. Mbuya MNN, Humphrey JH. Preventing environmental enteric dysfunction through improved water, sanitation and hygiene: an opportunity for stunting reduction in developing countries. Matern Child Nutr. 2016;12:106-120. https://doi.org/10. 1111/mcn.12220.

26. DeBoer MD, Scharf RJ, Leite AM, et al. Systemic inflammation, growth factors, and linear growth in the setting of infection and malnutrition. Nutrition. 2017;33:248-253. https://doi.org/10.1016/j.nut.2016.06.013. 